\title{
B Lymphocytes in Untreated Patients with Malignant Lymphoma and Hodgkin's Disease
}

\author{
Kazimiera J. Gajl-Peczalska, John A. Hansen, Clara D. Bloomfield, \\ and RoBert A. Goop \\ From the Departments of Pathology, Pediatrics, and Medicine and Section of \\ Medical Oncology, University of Minnesota, Minneapolis, Minnesota 55455
}

\begin{abstract}
A B S TR A C T B and T lymphocytes in 37 untreated patients with malignant lymphoma and Hodgkin's disease were studied. $\mathrm{B}$ cells in the peripheral blood were investigated with respect to surface immunoglobulins and in a few patients with respect to intracytoplasmic immunoglobulins by means of immunofluorescence. $\mathrm{T}$ cell function was studied by direct phytohemagglutinin (PHA) microtest (from the same sample of whole blood), mixed lymphocyte culture (MLC), and by delayed hypersensitivity to various antigens. In the 13 patients with Hodgkin's disease the histologic subtype was nodular sclerosis in nine, lymphocyte predominant in two, mixed cellularity in two. Only one of these patients had disseminated disease (stage IV); he showed impaired cellular immunity, a very low percentage of $\mathrm{B}$ cells and low levels of serum immunoglobulins. Of the remaining patients with Hodgkin's disease, with one exception, normal percentages but rather low absolute numbers of $B$ lymphocytes per $\mathrm{mm}^{3}$ of blood were found. One patient with a low percent and low absolute number of $\mathrm{B}$ lymphocytes showed very high serum IgG. Of 24 patients with non-Hodgkin's malignant lymphoma, seven (29\%) showed monoclonal $\mathrm{B}$ cell proliferation in the peripheral blood (five $\mu \kappa$, two $\gamma \kappa)$. By morphologic criteria, 14 patients had involvement of bone marrow, five of these had involvement of peripheral blood. Four of the latter five patients showed marked increases in percentages and absolute numbers of B lymphocytes in the peripheral blood reflecting the monoclonal proliferation. In three additional patients monoclonal proliferation of lymphocytes was found by immunofluorescence although the blood smears ap-
\end{abstract}

Dr. Hansen is a Special Fellow of the Leukemia Society of America.

Dr. Good's present address is President and Director, Memorial Sloan-Kettering Cancer Center, New York 10021.

Received for publication 15 May 1973 and in revised form 25 July 1973. peared morphologically normal. Serum immunoglobulin abnormalities without monoclonal B cell proliferation in the peripheral blood were observed in six patients.

\section{INTRODUCTION}

Detection by immunofluorescence of plasma membraneassociated immunoglobulins on lymphocytes provides a direct and reliable method to study $\mathbf{B}$ lymphocytes in human and other species (1). Studied by immunofluorescence, immunoglobulins seem to be present on the majority of $B$ cells and absent from the surface of $T$ cells (2-5). Independent and also cooperative roles for $\mathrm{B}$ and $\mathrm{T}$ cells in the immune response were postulated some time ago (6-8) and have now been confirmed (910). Immunologic mechanisms of defense against infections and neoplasms appear to depend on the function of these two populations of lymphocytes (11-13). The $B$ or $T$ origins of chronic and acute lymphocytic leukemia and the $\mathrm{B}$ and $\mathrm{T}$ cells in primary immunodeficiency diseases have been studied rather extensively (14-24). In these conditions the primary involvement of lymphocytes is readily apparent. However, at present, less is known about $\mathrm{B}$ cells in the malignant lymphomas, including Hodgkin's disease. The lymphomas probably represent a rather heterogeneous group of diseases. Moreover, duration of disease and treatment seems to influence the peripheral blood and bone marrow. All these factors may account for the somewhat conflicting observations that have already appeared (25-27).

The present study evaluates $\mathrm{B}$ and $\mathrm{T}$ cell populations in the peripheral blood of recently diagnosed, untreated patients with malignant lymphomas and Hodgkin's disease. Special emphasis was placed on examining both $\mathrm{B}$ and $\mathrm{T}$ cell populations in blood samples drawn on the same day. The $B$ lymphocytes were quantified by means of plasma membrane-associated immuno- 
globulins, the $\mathrm{T}$ lymphocyte function by response to phytohemagglutinin (PHA) in direct micromethod of whole blood (28), and in some cases by stimulation with allogeneic lymphocytes in mixed lymphocyte culture (MLC). Quantitative serum immunoglobulin levels and skin delayed hypersensitivity reactions to various antigens supplemented the evaluation of cellular and humoral immunity in the patients studied.

\section{METHODS}

Paticnts. Patients studied were newly diagnosed cases of malignant lymphoma seen at the University of Minnesota Hospitals between June 1972 and June 1973. The histologic diagnosis of the non-Hodgkin's malignant lymphomas was based on the Lukes' modification of the Rappaport classification (29). The diagnosis of Waldenström's macroglobulinemia was based on the criteria of Rappaport (30). The cases of Hodgkin's disease were subclassified after Lukes, Butler, and Hicks (31). Patients with both Hodgkin's and non-Hodgkin's malignant lymphoma were staged according to the recommendations of the 1971 Ann Arbor Conference on Staging in Hodgkin's Disease (32). In all patients evaluation included bilateral iliac crest trephine bone marrow biopsies, lymphangiograms, and percutaneous liver biopsy. Patients with Hodgkin's disease underwent exploratory laparotomies if they were initially not of stage IV. Patients with non-Hodgkin's malignant lymphoma also had complete gastrointestinal X-rays and laparotomies if they were initially of clinical stage I or II.

Lymphocytes. Blood from patients was collected in heparin. One part was used for quantitative response to phytohemagglutinin in direct microtest (28), and to determine white blood total and differential counts. The remaining blood was separated on Ficoll-Hypaque gradient for isolation of lymphocytes as previously described (24). These lymphocytes were used for determination of B cells by immunofluorescence and in some cases for "one-way" stimulation by allogeneic lymphocytes in mixed lymphocyte culture.

Immunofluorescence. Monospecific antisera directed against the major heavy-chain classes $(\alpha, \mu, \gamma)$ were obtained from goats and conjugated with fluorescein isothiocyanate as previously described (24). Antisera directed against $\epsilon$ heavy and $\kappa$ - and $\lambda$-light chains were purchased from Meloy Laboratories Inc. (Sprinfield, Va.) and checked for specificity by immunoelectrophoresis, gel double diffusion, and absorption with appropriate antigens. The pure IgEmyeloma from McIntyre's case was a gift from Dr. Alfred Michael. Immunofluorescent staining was carried out as previously described (24). 400-500 cells were evaluated on every slide using the Zeiss ultraviolet microscope (Carl Zeiss, Inc.. New York) (24). In some cases an additional aliquot of unstained cells was spun in a cytocentrifuge (Shandon-Elliott, London, England) and after fixation for $5 \mathrm{~min}$ in absolute alcohol stained for the detection of intracytoplasmic immunoglobulins using the same fluoresceinated antisera in appropriate dilutions. For checking the cap formation the immunofluorescent staining was carried out at ice-bath temperature but in the absence of sodium azide. The slides were examined after being kept at room temperature for $30-45 \mathrm{~min}$.

Immunoglobulin determination. Quantitation of serum immunoglobulins was performed by single radial immunodiffusion using commercial plates (Hyland Div., Travenol Lahoratories, Costa Mesa, Calif.). The monoclonal component $(\mathrm{M})$ of serum immunoglobulins was detected by electrophoresis in cellulose acetate strips and subsequently by immunoelectrophoresis in agar-gel against monospecific anti- $\kappa$ and anti- $\lambda$ antisera (Behring Diagnostics).

PHA response. The PHA response was determined by the direct micromethod using $50 \mu 1$ of peripheral blood. Lymphocyte stimulation was performed with three different concentrations of PHA and the maximum response from this dose-curve was used to determine the stimulation ratio by labeling with tritiated thymidine ([stimulated culture, cpm]/[unstimulated culture, cpm]) (28).

Mircd lymphocyte culture. The "one-way" mixed lymphocyte culture was performed using isolated lymphocytes. $10^{5}$ responder lymphocytes and $10^{5}$ mitomycin-C treated stimulatory (allogeneic) lymphocytes were incubated in $1.0 \mathrm{ml}$ of culture medium (RPMI 1640) with $15 \%$ pooled normal human male serum. Lymphocyte transformation was quantified by labeling with $\left[2-{ }^{14} \mathrm{C}\right]$ thymidine (New England Nuclear Corp., Boston, Mass.). All cultures were performed in triplicate.

Skin tests. The skin tests used for evaluation of $\mathrm{T}$ lymphocyte function were as follows: PPD, mumps, trichophyton, candida, and streptokinase-streptodornase. Response (erythema and induration of $5 \mathrm{~mm}$ or more at $24-48 \mathrm{~h}$ ) to at least one of the antigens was considered a positive result.

\section{RESULTS}

On the basis of the histological classification, the 37 patients were divided into three groups: (a) Hodgkin's disease, (b) malignant lymphoma, and (c) lymphoma-special types (Tables I, III, and V).

Hodgkin's discase. This group comprised 13 patients (Table I). Seven were under $30 \mathrm{yr}$ of age. All but two who were classified histologically as mixed cellularity type were found to have either lymphocyte predominant or nodular sclerosis type of Hodgkin's disease; all but three were classified clinically as stage I or II. Five patients presented with low lymphocyte counts in the peripheral blood; four of these had negative or low PHA response. However, the skin tests were positive in four of the five patients who were tested, and the mixed lymphocyte culture was positive in all cases tested.

In nine patients the percentage of $B$ lymphocytes in the peripheral blood falls within the normal range for our laboratory, as well as for other laboratories, that is, $15-29 \%$ (Table II). ${ }^{1}$ Two patients (nos. 2 and 7) showed very low percentages of $\mathrm{B}$ cells. In patient no. 2 this abnormality was accompanied by low levels of serum immunoglobulins, but in patient no. 7 by an elevated serum IgG level. In all patients the distribution of inmunoglobulins on lymphocytes as well as the capacity for cap formation were similar to those observed

${ }^{1}$ The total Ig-bearing lymphocytes is the sum of the percent cells stained with anti- $\gamma,-\mu,-\alpha$, and $-\epsilon$ antiserums. Mean values for normals in this study are lower than those reported in the previous paper (24). This is especially true for IgG-bearing lymphocytes and is related to the improved methodology for eliminating monocytes. 
TABLE I

Hodgkin's Diesase

\begin{tabular}{|c|c|c|c|c|c|c|c|c|}
\hline Patient & Age & Sex & Diagnosis* & Stage & $\begin{array}{c}\text { Lymphocyte } \\
\text { count } \\
\text { (per } \mathrm{mm}^{2} \text { ) }\end{array}$ & MLC & PHA $\ddagger$ & $\begin{array}{l}\text { Skin } \\
\text { tests }\end{array}$ \\
\hline 1. L. W. & 75 & M & L.P. & I A & 1,898 & + & Neg & + \\
\hline 2. G. S. & 42 & $\mathrm{M}$ & L.P. & IV A & 1,802 & ND & $\mathrm{L}$ & - \\
\hline 3. E. K. & 26 & F & N.S. & $\mathrm{II}_{\mathrm{E}} \mathrm{A}$ & 945 & + & Neg & ND \\
\hline 4. S. W. & 12 & $\mathrm{~F}$ & N.S. & II A & 1,121 & + & $\mathrm{N}$ & - \\
\hline 5. A. V. & 56 & $\mathrm{M}$ & N.S. & III A & 700 & ND & L & + \\
\hline 6. C. A. & 25 & M & N.S. & II B & 270 & + & Neg & + \\
\hline 7. J. M. & 61 & M & N.S. & II B & 1,750 & ND & Neg & + \\
\hline 8. I. S. & 79 & $\mathrm{~F}$ & N.S. & II B & 1,377 & + & $\mathrm{N}$ & + \\
\hline 9. J. H. & 17 & M & N.S. & II A & 1,683 & + & $\mathrm{N}$ & + \\
\hline 10. M. R. & 20 & $\mathbf{M}$ & N.S. & III A & 1,470 & + & $\mathrm{L}$ & + \\
\hline 11. D. L. & 26 & M & N.S. & II B & 875 & + & $\mathrm{L}$ & + \\
\hline 12. D. K. & 18 & M & M.C. & II A & 1,910 & + & $\mathrm{N}$ & + \\
\hline 13. K. H. & 30 & $\mathrm{~F}$ & M.C. & II B & 2,651 & + & $\mathrm{N}$ & + \\
\hline
\end{tabular}

* L.P., lymphocyte predominant ; N.S., nodular sclerosis; M.C., mixed cellularity.

¥ Stimulated cpm/unstimulated cpm, normal (N) $>20$, low (L) 10-20, negative (Neg) <10; ND, not done.

in normal individuals. The percentages of lymphocytes bearing receptors of different heavy and light chains did not show significant differences when compared with normal controls. Only the absolute numbers of circulating B lymphocytes tended to be low. This is understandable since the lymphocyte counts were often low and the percentages of B lymphocytes were within normal limits.

Malignant lymphoma. This group comprised 20 patients, ranging in age from 35 to $87 \mathrm{yr}$ (Table III). They represented different histological types of lym- phoma. The largest group consisted of nine patients diagnosed as having diffuse poorly-differentiated lymphocytic lymphoma. 15 of 20 patients were of stage IV : 14 exhibited bone marrow involvement. In contrast with Hodgkin's disease, only three patients presented with a low lymphocyte count. One of them (patient no. 17) was $86 \mathrm{yr}$ old and was found to have negative skin tests. This patient also had a very low percentage and absolute number of $\mathrm{B}$ lymphocytes. All other patients, except five who were not tested, had positive delayed hypersensitivity skin reactions but

TABLE II

$B$ Cell Evaluation in Hodgkin's Disease

\begin{tabular}{|c|c|c|c|c|c|c|c|c|c|c|c|}
\hline \multirow[b]{2}{*}{ Patient } & \multicolumn{6}{|c|}{ Surface Ig on lymphocytes } & \multirow[b]{2}{*}{ Total } & \multirow{2}{*}{$\begin{array}{l}\text { Circulating } \\
\text { B lympho- } \\
\text { cytes } \\
\left(\text { per } \mathrm{mm}^{3}\right)\end{array}$} & \multicolumn{3}{|c|}{ Serum Ig } \\
\hline & $\gamma \mathbf{M}$ & $\gamma \mathrm{G}$ & $\gamma \mathrm{A}$ & $\gamma \mathrm{E}$ & Kappa & Lambda & & & $\operatorname{IgM}$ & IgG & $\operatorname{IgA}$ \\
\hline 1 & 9.4 & 7.4 & 1.0 & ND & 10.6 & 10.3 & 20 & 380 & 66 & $\begin{array}{c}m g / 100 \mathrm{ml} \\
1,460\end{array}$ & 273 \\
\hline 2 & 3.0 & 2.7 & 0 & 1.0 & 4.5 & 2.0 & 6 & 108 & $<10$ & 880 & 80 \\
\hline 3 & 7.0 & 8.0 & 1.5 & 1.0 & 12.5 & 4.8 & 17 & 160 & 96 & 1,420 & 177 \\
\hline 4 & 8.3 & 5.3 & 0.3 & ND & 7.0 & 5.0 & 13 & 146 & 108 & 1,710 & 300 \\
\hline 5 & 7.6 & 5.2 & 1.2 & 0.6 & 6.8 & 6.8 & 14 & 98 & ND & ND & ND \\
\hline 6 & 21.5 & 8.5 & 4.5 & ND & ND & ND & 34 & 92 & 76 & 1,670 & 143 \\
\hline 7 & 2.2 & 0.6 & 1.0 & ND & 1.6 & 1.3 & 4 & 47 & 65 & 4,020 & 280 \\
\hline 8 & 7.0 & 11.0 & 7.0 & 0 & 14.0 & 14.0 & 25 & 344 & 86 & 1,180 & 275 \\
\hline 9 & 11.3 & 6.2 & 2.0 & ND & 16.0 & 11.7 & 18 & 303 & 120 & 1,720 & 300 \\
\hline 10 & 4.0 & 5.5 & 3.5 & 0.5 & 5.5 & 8.0 & 13 & 191 & 57 & 1,470 & 242 \\
\hline 11 & 14.0 & 6.5 & 2.7 & 1.0 & 12.5 & 8.8 & 22 & 192 & 66 & 1,300 & 190 \\
\hline 12 & 7.7 & 14.8 & 1.7 & $\mathbf{0}$ & 11.5 & 9.5 & 24 & 468 & 57 & 1,640 & 231 \\
\hline 13 & 5.4 & 14.0 & 0.7 & 0.7 & 16.0 & 9.0 & 21 & 557 & 124 & 2,460 & 238 \\
\hline \multicolumn{12}{|l|}{ Controls } \\
\hline $\begin{array}{l}\text { Mean } \\
\text { Range }\end{array}$ & $\begin{array}{c}8.8 \\
(4.4-13.7)\end{array}$ & $\begin{array}{c}8.6 \\
(4.1-16.3)\end{array}$ & $\begin{array}{c}4.2 \\
(0.8-8.7)\end{array}$ & $\begin{array}{c}0.9 \\
(0-1.5)\end{array}$ & $\begin{array}{c}13.7 \\
(8.2-21.9)\end{array}$ & $\begin{array}{c}7.8 \\
(3.4-14.1)\end{array}$ & $\begin{array}{c}21 \\
(14-33)\end{array}$ & $\begin{array}{c}401 \\
(298-610)\end{array}$ & $36-280$ & $520-1,800$ & 44-540 \\
\hline
\end{tabular}


TABLE III

Malignant Lymphoma

\begin{tabular}{|c|c|c|c|c|c|c|c|c|c|c|c|}
\hline \multirow{2}{*}{\multicolumn{2}{|c|}{ Patient }} & \multirow[b]{2}{*}{ Age } & \multirow[b]{2}{*}{ Sex } & \multirow[b]{2}{*}{ Diagnosis* } & \multirow[b]{2}{*}{ Stage } & \multicolumn{2}{|c|}{ Involvement‡ } & \multirow{2}{*}{$\begin{array}{c}\text { Lymphocyte } \\
\text { count } \\
\text { (per } \mathrm{mm}^{3} \text { ) }\end{array}$} & \multirow[b]{2}{*}{ MLC } & \multirow[b]{2}{*}{ PHA\& } & \multirow[b]{2}{*}{$\begin{array}{l}\text { Skin } \\
\text { tests }\end{array}$} \\
\hline & & & & & & Blood & $\begin{array}{c}\text { Bone } \\
\text { marrow }\end{array}$ & & & & \\
\hline 1. & G. B. & 52 & $\mathrm{M}$ & PDL-N & IV A & - & + & 1,960 & + & L & + \\
\hline 2. & F.C. & 87 & M & PDL-N & IV A & $t$ & + & 2,700 & + & Neg & + \\
\hline 3. & F. V.E. & 65 & M & PDL-N & IV A & - & + & 950 & ND & $\mathrm{Neg}$ & ND \\
\hline 4. & J. L. V. & 35 & M & PDL-N & IV A & + & + & 33,760 & ND & ND & ND \\
\hline 5 & W.F. & 68 & M & WDL-D & IV A & - & + & 2,750 & ND & $\mathrm{L}$ & ND \\
\hline 6. & A. B. & 67 & $\mathrm{~F}$ & PDL-D & II A & - & - & 630 & + & $\mathrm{L}$ & + \\
\hline 7. & W. G. & 47 & $\mathrm{M}$ & PDL-D & II A & - & - & 1,540 & ND & Neg & + \\
\hline 8. & M. L. & 56 & $\mathrm{~F}$ & PDL-D & IV A & + & + & 2,030 & + & $\mathrm{L}$ & + \\
\hline 9. & L. P. & 40 & $\mathrm{~F}$ & PDL-D & IV A & + & + & 2,860 & + & $\mathrm{L}$ & + \\
\hline 10. & R. B. & 61 & $\mathrm{~F}$ & PDL-D & IV A & - & + & 1,363 & ND & Neg & ND \\
\hline 11. & II. A. & 76 & $\mathrm{M}$ & PDL-D & IV A & - & + & 1,487 & ND & $\mathbf{N}$ & + \\
\hline 12. & F. B. & 59 & $\mathrm{~F}$ & PDL-D & IV A & - & - & 2,380 & + & Neg & + \\
\hline 13. & R. M. & 42 & M & PDL-D & IV B & - & + & 6,432 & + & Neg & + \\
\hline 14. & O. S. & 47 & $\mathrm{M}$ & PDL-D & IV A & - & + & 1,170 & + & $\mathrm{N}$ & + \\
\hline 15. & U. K. & 79 & $\mathrm{M}$ & $\mathrm{H}-\mathrm{N}$ & III B & - & - & 1,651 & ND & ND & + \\
\hline & N. K. & 59 & $\mathrm{~F}$ & H-D & III A & - & - & 1,875 & ND & $N$ & + \\
\hline 17. & G. F. & 86 & $\mathbf{M}$ & H-D & II A & - & - & 360 & ND & $\mathrm{Neg}$ & - \\
\hline 18. & E. II. & 61 & $\mathrm{~F}$ & $\mathrm{~L}-\mathrm{U}$ & IV B & - & - & 1,173 & + & Neg & + \\
\hline 19. & T. M. & 63 & $\mathbf{M}$ & L-U & IV B & - & + & 1,300 & ND & Neg & + \\
\hline 20. & M. D. & 75 & $\mathrm{~F}$ & $\mathrm{II}-\mathrm{M}$ & IV A & + & + & 12,301 & ND & $\mathrm{Neg}$ & ND \\
\hline
\end{tabular}

* PDL-N, poorly-differentiated lymphocytic-nodular; PDL-D, poorly-differentiated lymphocytic-diffuse; WDL-D, well differentiated lymphocytic-diffuse; H-N, histiocytic-nodular; H-D, histiocytic-diffuse; L-U, lymphoma, type unspecified; W-M, Waldenström's macroglobulinemia.

$\ddagger$ Involvement of bone marrow and peripheral blood by morphologic criteria.

$\S$ Stimulated cpm/unstimulated cpm; normal (N) $>20$, low (L) 10-20, negative (Neg) <10; ND, not done.

many of them had negative direct PHA microtests. However, the MLC was positive in all cases in which it was done (Table III).

In contrast to the patients with Hodgkin's disease, the group of lymphoma patients frequently demonstrated abnormalities in the $B$ cell population manifested by increased absolute numbers, changed percentages of $\mathrm{B}$ cells and changed immunoglobulin type on B lymphocytes in peripheral blood, as well as abnormal serum immunoglobulin levels (Table IV). In five patients with bone marrow involvement, the peripheral blood was also morphologically involved with lymphoma. Four of these five patients showed proliferation of $\mathrm{B}$ cells with monoclonal immunoglobulin bound to their plasma membranes. In patients nos. 9 and 20, it was $\mu \kappa$, in patient no. $2, \gamma \kappa$. Patient no. 4 presented proliferation of lymphocytes bearing $\mu$-heavy chain but the determination of surface-associated light chain was not done. In two patients, the serum IgM level was low; in one it was high and of monoclonal character (patient no. 20-Waldenström's macroglobulinemia). In two additional patients who did not show a significant increase in white blood count and in whom the lymphocyte population appeared normal morphologically, the immunofluorescence study demonstrated monoclonal proliferation of B lymphocytes (patients nos. 13 and 18 ). In patient no. 13, the proliferating lymphocytes possessed $\mu \kappa$-membrane-associated immunoglobulin. Unfortunately, because of a technical error, we do not have the percent of $\gamma$-receptors in this case. This is the reason for the question mark in Table IV. The serum $\operatorname{IgM}$ of this patient was very low but other immunoglobulins fell within the normal range. $\mathrm{Pa}$ tient no. 18 showed more than $50 \%$ of blood lymphocytes to have membrane-associated $\gamma \kappa$. The levels of serum immunoglobulins were normal in this patient.

The remaining 14 patients showed normal percentages of B lymphocytes with normal distribution among different heavy and light chain classes. The absolute numbers of $B$ cells were not significantly abnormal. In one of these patients a small number of malignant cells was present in the peripheral blood on hematologic evaluation, but the immunofluorescence analysis did not show an abnormality reflecting clonal proliferation (patient no. 8). In 6 of the 14 patients, low levels of serum immunoglobulins were seen; patients nos. 1, 6, 


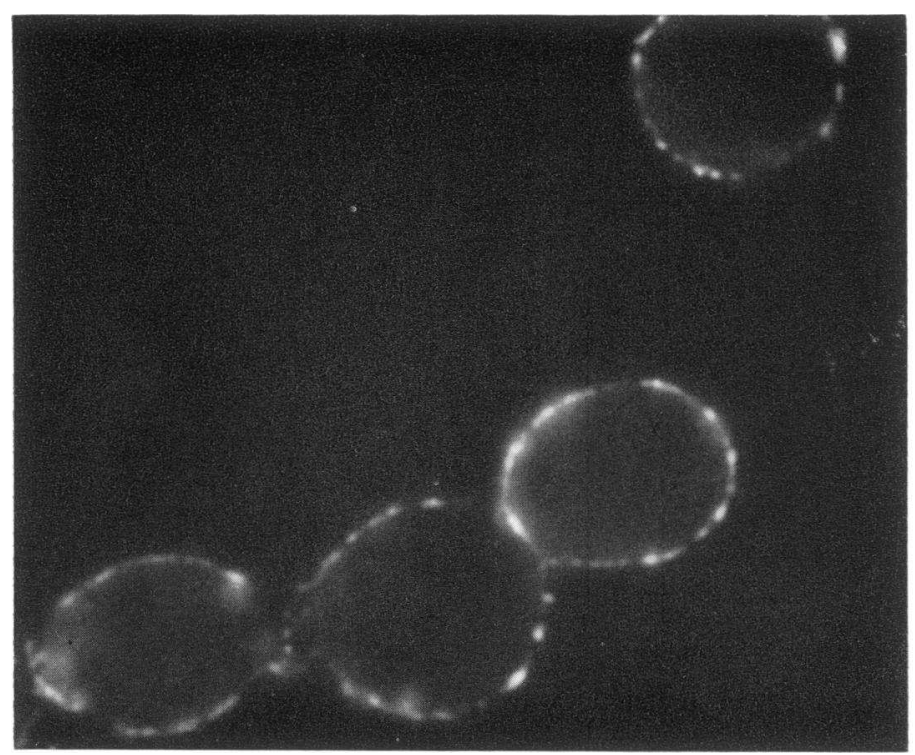

FIgURE 1 Plasma membrane-associated $\operatorname{IgM}(\mu)$ in the case of Waldenström's macroglobulinemia. Note uniform, bright fluorescence of all lymphocytes. $(\times 1,000)$

and 11 had low levels of $\operatorname{IgM}$; patients nos. 3 and 10 , of IgG; and patient no. 14 of IgA.

Patient no. 20 with Waldenström's macroglobulinemia deserves special comment. The peripheral white blood count was 20,850 with $10 \%$ lymphocytes and
49\% lymphoblasts. Virtually all circulating lymphoid cells showed membrane-associated $\mu \kappa$-immunoglobulin (Fig. 1). The distribution of these receptors was rather uniform, in the form of small "dots." The fluorescent staining was of much higher intensity than that seen

TABLE IV

$B$ Cell Evaluation in Malignant Lymphoma

\begin{tabular}{|c|c|c|c|c|c|c|c|c|c|c|c|}
\hline \multirow[b]{2}{*}{ Patient } & \multicolumn{6}{|c|}{ Surface Ig on lymphocytes } & \multirow[b]{2}{*}{ Total } & \multirow{2}{*}{$\begin{array}{l}\text { Circulating } \\
\text { B lympho- } \\
\text { cytes } \\
\left(\text { per } \mathrm{mm}^{3}\right)\end{array}$} & \multicolumn{3}{|c|}{ Serum Ig } \\
\hline & $\gamma \mathbf{M}$ & $\gamma \mathrm{G}$ & $\gamma \mathrm{A}$ & $\gamma \mathrm{E}$ & Kappa & Lambda & & & $\operatorname{IgM}$ & IgG & IgA \\
\hline & & & & & & & & & \multicolumn{3}{|c|}{$m g / 100 m l$} \\
\hline 1 & 5.0 & 6.5 & 2.2 & 1.5 & 6.7 & 5.6 & 15 & 294 & 10 & 1,540 & 188 \\
\hline 2 & 1.4 & 41.7 & 0.7 & 0.3 & 37.7 & 0.3 & 44 & 1,188 & 32 & 1,250 & 270 \\
\hline 3 & 3.0 & 5.2 & 1.2 & 1.6 & 5.4 & 3.6 & 11 & 104 & 44 & 464 & 81 \\
\hline 4 & 56.6 & 3.2 & 6.0 & ND & ND & ND & 66 & 22,281 & ND & ND & ND \\
\hline 5 & 10.0 & 22.0 & 1.0 & ND & 14.2 & 15.0 & 33 & 907 & 62 & 1,200 & 151 \\
\hline 6 & 8.2 & 10.0 & 1.5 & 2.2 & 17.0 & ND & 22 & 138 & 24 & 890 & 205 \\
\hline 7 & 4.0 & 11.0 & 0.5 & 1.0 & 10.5 & 6.5 & 17 & 261 & 115 & 1,080 & 62 \\
\hline 8 & 11.6 & 9.7 & 4.2 & ND & 12.7 & 12.5 & 25 & 507 & 76 & 1,450 & 342 \\
\hline 9 & 19.2 & 11.7 & 4.5 & 0 & 30.2 & 6.5 & 35 & 1,001 & 90 & 820 & 70 \\
\hline 10 & 8.8 & 7.4 & 0 & ND & ND & 1.8 & 16 & 218 & 70 & 88 & 70 \\
\hline 11 & 3.7 & 5.7 & 3.0 & 1.3 & ND & ND & 14 & 208 & 26 & 900 & 594 \\
\hline 12 & 7.3 & 18.3 & 4.7 & 1.0 & 21.3 & 6.5 & 31 & 737 & 81 & 1,420 & 370 \\
\hline 1.3 & 52.2 & ?* & 0.4 & 0.2 & 70.4 & 14.8 & 85 & 5,267 & 22 & 1,280 & 238 \\
\hline 14 & 3.0 & 2.3 & 2.7 & 0 & 8.7 & 4.3 & 8 & 93 & 37 & 680 & 33 \\
\hline 15 & 1.7 & 8.5 & 0.3 & 0 & 8.0 & 2.0 & 10 & 165 & 100 & 1,230 & 630 \\
\hline 16 & 11.5 & 7.0 & 4.3 & 0.7 & 8.7 & 11.2 & 23 & 431 & 82 & 1,380 & 195 \\
\hline 17 & 2.5 & 2.0 & 0.5 & 0.5 & 3.0 & 7.0 & 10 & 36 & 330 & 1,490 & 131 \\
\hline 18 & 6.0 & 58.4 & 1.0 & ND & 53.4 & 5.2 & 65 & 762 & 57 & 1,030 & 260 \\
\hline 19 & 4.3 & 3.3 & 2.0 & 0.3 & 6.7 & 4.5 & 10 & 130 & ND & ND & ND \\
\hline 20 & 99.3 & 0.3 & 0 & ND & 99.6 & 0 & 100 & 12,301 & 2,450 & 560 & 104 \\
\hline \multicolumn{12}{|l|}{ Controls } \\
\hline Mean & 8.8 & 8.6 & 4.2 & 0.9 & 13.7 & 7.8 & 21 & 401 & & & \\
\hline Range & $(4.4-13.7)$ & $(4.1-16.3)$ & $(0.8-8.7)$ & $(0-1.5)$ & $(8.2-21.9)$ & $(3.4-14.1)$ & $(14-33)$ & $(298-610)$ & $36-280$ & $520-1,800$ & 44-540 \\
\hline
\end{tabular}

* ? indicates that because of technical error the percentage is not available.

3068 K. J. Gajl-Peczalska, J. A. Hansen, C. D. Bloomfield, and R. A. Good 


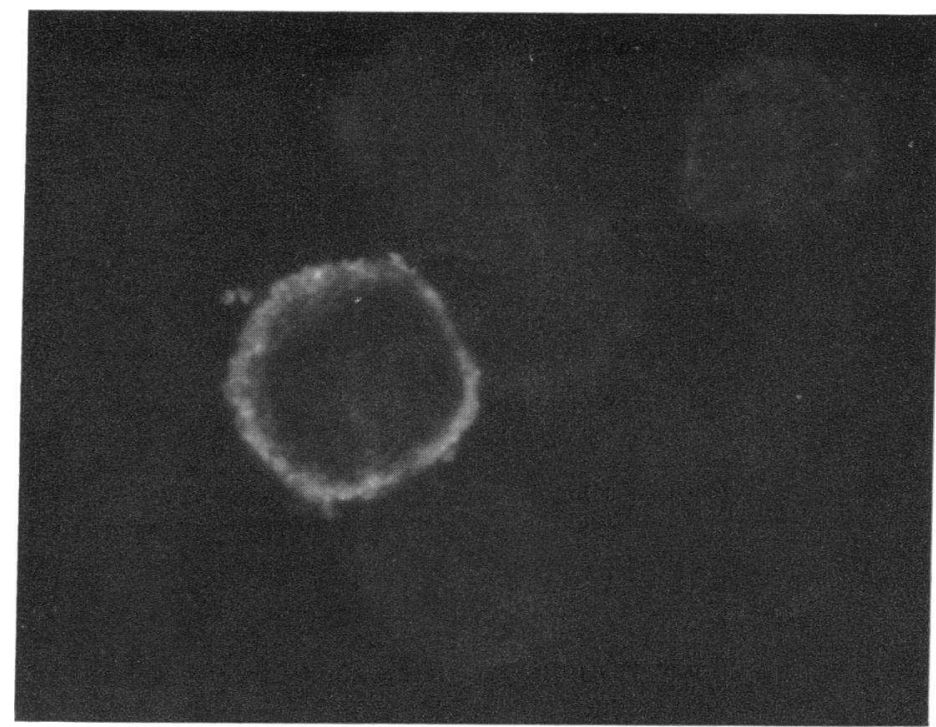

FIGURE 2 Intracytoplasmic $\operatorname{IgM}(\mu)$ in medium-size lymphocytes in the case of Waldenström's macroglobulinemia. $(\times 1,000)$

in chronic lymphocytic leukemia. When stained for intracytoplasmic immunoglobulins, only $0.7 \%$ of cells contained $\mu \kappa$-immunoglobulin; all of them were either medium-size or large lymphocytes (Fig. 2). The bone marrow of this patient also was involved but, unfortunately, we did not have an opportunity to study it by immunofluorescence. The serum immunoglobulins showed markedly increased IgM of monoclonal $\mu \kappa$-type, the same as was observed on the surface of circulating lymphocytes and in the cytoplasm of some larger lymphocytic cells. The IgG level was slightly decreased.

Lymphoma, special types. This group consisted of four patients with unusual tumors (Table V). Reticulum cell sarcoma of the brain can not be histologically distinguished from microgliomatosis of the brain (33). Malignant lymphoma of the eyelid is also considered a special case (34). Lymphoepithelioma of the lacrimal gland is a distinct entity both histologically and clinically because of its relationship to Sjögren's syndrome and its apparently benign clinical course (35). All four patients were staged as extralymphatic localized involvement, Is A. All showed normal cell-mediated immunity as measured by direct PHA microtest and by skin tests. Patient no. 1 is the only one who presented an abnormal B cell population in the peripheral blood with increased percentage of $B$ lymphocytes on two evaluations performed three months apart (Table VI). Both times monoclonal $\mu \kappa$-bearing lymphocytes prevailed. Moreover, this patient showed markedly elevated serum $\operatorname{IgM}$ and decreased $\operatorname{IgG}$ and $\operatorname{IgA}$ but without evidence of a monoclonal globulin spike in cellulose acetate strip electrophoresis or in immuno-

TABLE V

Lymphoma-Special Type

\begin{tabular}{|c|c|c|c|c|c|c|c|c|c|}
\hline \multirow[b]{2}{*}{ Patient } & \multirow[b]{2}{*}{ Age } & \multirow[b]{2}{*}{ Sex } & \multirow[b]{2}{*}{ Diagnosis } & \multirow[b]{2}{*}{ Stage } & \multicolumn{2}{|c|}{ Involvement } & \multirow{2}{*}{$\begin{array}{l}\text { Lymphocyte } \\
\text { count } \\
\text { (per } \mathrm{cmm} \text { ) }\end{array}$} & \multirow[b]{2}{*}{ PHA* } & \multirow[b]{2}{*}{$\begin{array}{l}\text { Skin } \\
\text { tests }\end{array}$} \\
\hline & & & & & Blood & $\begin{array}{l}\text { Bone } \\
\text { marrow }\end{array}$ & & & \\
\hline 1. M. M. & 39 & $F$ & $\begin{array}{l}\text { Lymphoepithelioma of } \\
\text { lacrimal gland }\end{array}$ & $\mathrm{I}_{E} \mathrm{~A}$ & - & - & 2,550 & $\mathrm{~N}$ & + \\
\hline 2. A. H. & 55 & F & $\begin{array}{l}\text { Malignant lymphoma- } \\
\text { fornix of the eye }\end{array}$ & $\mathrm{I}_{\mathrm{E}} \mathrm{A}$ & - & - & 3,465 & $\mathrm{~N}$ & + \\
\hline 3. L. S. & 54 & $\mathrm{~F}$ & $\begin{array}{l}\text { Reticulum cell } \\
\text { sarcoma of the brain }\end{array}$ & $\mathrm{I}_{E} \mathrm{~A}$ & - & - & 760 & $\mathrm{~N}$ & ND \\
\hline 4. L. H. & 75 & F & $\begin{array}{l}\text { Reticulum cell } \\
\text { sarcoma of the brain }\end{array}$ & $\mathrm{I}_{\mathrm{E}} \mathrm{A}$ & - & - & 2,484 & Neg & + \\
\hline
\end{tabular}

* Stimulated cpm/unstimulated cpm; normal $(\mathrm{N})>20$, low $(\mathrm{L})$ 10-20, negative $(\mathrm{Neg})<10$; ND, not done. 
TABLE VI

B Cell Evaluation in Lymphoma-Special Type

\begin{tabular}{|c|c|c|c|c|c|c|c|c|c|c|c|}
\hline \multirow[b]{2}{*}{ Patient } & \multicolumn{6}{|c|}{ Surface Ig on lymphocytes } & \multirow[b]{2}{*}{ Total } & \multirow{2}{*}{$\begin{array}{l}\text { Circulating } \\
\text { B lympho- } \\
\text { cytes } \\
\text { (per } \mathrm{mm}^{\mathbf{s}} \text { ) }\end{array}$} & \multicolumn{3}{|c|}{ Serum Ig } \\
\hline & $\gamma \mathbf{M}$ & $\gamma \mathrm{G}$ & $\gamma \mathbf{A}$ & $\gamma \mathrm{E}$ & Kappa & Lambda & & & $\operatorname{Ig} M$ & IgG & $\operatorname{IgA}$ \\
\hline & & & & & & & & & & $m g / 100 \mathrm{ml}$ & \\
\hline \multirow[t]{2}{*}{1} & 27.9 & 8.7 & 3.2 & 0.5 & 37.9 & 7.2 & 45 & 1,137 & 768 & 256 & 18 \\
\hline & 45.3 & 4.3 & 1.3 & ND & 35.0 & 9.3 & 45 & & & & \\
\hline 2 & 10.0 & 10.3 & 4.0 & 1.3 & 20.0 & 7.0 & 27 & 935 & 73 & 1,150 & 293 \\
\hline 3 & 10.3 & 6.3 & 2.3 & 1.0 & 8.7 & 6.3 & 17 & 129 & 326 & 760 & 119 \\
\hline 4 & 4.5 & 14.0 & 3.0 & 0.5 & 11.0 & 12.2 & 23 & 546 & 30 & 840 & 311 \\
\hline \multicolumn{12}{|l|}{ Controls } \\
\hline Mean & 8.8 & 8.6 & 4.2 & 0.9 & 13.7 & 7.8 & 21 & 401 & & & \\
\hline Range & $(4.4-13.7)$ & $(4.1-16.3)$ & $(0.8-8.7)$ & $(0-1.5)$ & $(8.2-21.9)$ & $(3.4-14.1)$ & $(14-33)$ & $(298-610)$ & $36-280$ & $520-1,800$ & $44-540$ \\
\hline
\end{tabular}

electrophoresis in agar-gel run against anti- $\kappa$ and anti- $\lambda$ antisera. However, a small amount of M-component might have been missed by these techniques. Repeated hematologic study failed to show the abnormal lymphocytes, by morphologic criteria, in the peripheral blood or in the bone marrow.

\section{DISCUSSION}

The findings reported here seem of interest from several points of view. We have reported studies of $B$ lymphocytes in the blood from a total of 24 patients with non-Hodgkin's lymphoma and 13 patients with Hodgkin's disease. Four of the former represent special forms of lymphoma in which the disease appeared only in unusual extralymphatic locations such as the eye or brain. We have focused on the number and nature of $B$ lymphocytes in blood (as revealed by analysis of surface immunoglobulins using immunofluorescence) and on the relation of the numbers of $B$ lymphocytes to serum immunoglobulin levels and to $\mathrm{T}$ cell functions. Interpretation of the observations on in vitro evaluation of $\mathrm{T}$ cell numbers and functions is complex. Analyses employing multiple stimuli, dose response curves and analysis of the influence of serum factors must be included in a comprehensive study. The data on this point included in our paper must be expanded in future studies to give more than crude information about $\mathrm{T}$ cell function. Our efforts in this direction with some of the patients included in this study and in an additional group of patients will be subsequently reported. ${ }^{2}$ In this study the MLC was uniformly positive, but the $\mathrm{PHA}$ response of whole blood lymphocytes was often low or negative. This finding could mean, simply, that inhibitors of PHA-

\footnotetext{
${ }^{2}$ Hansen, J. A., C. Bloomfield, K. J. Gajl-Peczalska, B. Dupont, and R. A. Good. In vitro lymphocyte responses in patients with Hodgkin's disease and non-Hodgkin's lymphoma. In preparation.
}

induced lymphocyte transformation are present in the blood. Although $\mathrm{T}$ lymphocyte-dependent immunological functions have often been shown to be depressed in patients with Hodgkin's disease (36-38), Young et al. have shown that $\mathrm{T}$ lymphocyte deficiencies may be minimal early in the course of Hodgkin's disease (39). Our results showing a deficiency of PHA responsiveness in some of these patients, as determined in our microculture system, may be indicative of quantitative differences in the function of these lymphocytes. Indeed, it has been shown that minimal deficiency of delayed skin reactivity may exist early in the course of Hodgkin's disease, but demonstration of any deficiencies requires the use of very critical doses of 2-4 DNCB for sensitization (40).

Deficits of $\mathrm{T}$ cells in patients with other diseases such as Di George's syndrome (23), leprosy (41), and sarcoidosis (42) are very often accompanied by increased percentages and increased absolute numbers of $B$ cells. Instead of revealing increased numbers of B lymphocytes, our cases of Hodgkin's disease presented rather decreased total numbers of $B$ cells and in two instances decreased percentages of B lymphocytes. Other investigators have reported increased percentages of B lymphocytes in Hodgkin's disease (2527). The differences may be explained on the basis of stage of disease and prior treatment given in their cases $(26,27)$. In one of our patients with Hodgkin's disease the circulating $B$ cell number and the percentage were very low. In serum taken at the same time, however, a markedly elevated IgG was found. We have seen similar discrepancies in two cases of multiple myeloma where B lymphocytes in the peripheral blood were very low even though large amounts of myeloma protein were being produced. ${ }^{3}$ Several possible explanations can be considered for these findings. Our patient with Hodgkin's disease had a severe

- Gaj1-Peczalska, K. J. Unpublished observations. 
chronic pulmonary infection at the time his B lymphocytes were quantified. It could be that depression of B lymphocytes reflects the stress of his disease operating through the pituitary-adrenal axis. Alternatively the chronic infection may have mobilized $B$ lymphocytes to the lung leading to a deficiency in the blood.

It is clear from our analysis that many non-Hodgkin's malignant lymphomas are of $\mathrm{B}$ cell origin and that this fact can frequently be established by application of relatively simple studies to the cells in the peripheral blood. In 6 of 20 patients with lymphoma, evidence of monoclonal proliferation of the $\mathrm{B}$ lymphocyte population was obtained. Furter, in one of four cases of the special type lymphoma, a lymphoepithelioma of the lacrimal gland, evidence of monoclonal proliferation of $\mathrm{B}$ lymphocytes was present. That these patients were experiencing a monoclonal expansion of B lymphocytes was established by the fact that cells having one class of immunoglobulin heavy chain and a single type of light chain prevailed in the blood. Since double fluorescent staining was not used in this investigation, the high percentages of cells staining for either a single heavy or a single light chain is not absolute proof for a single monoclonal population of lymphocytes. The remote possibility that these patients have two malignant clones, one bearing only heavy chain and one only light chain markers, however unlikely, cannot be excluded. Such a monoclonal expansion of $\mathrm{B}$ cells extending to the peripheral blood is, however not the rule in patients with lymphoma, even in instances where morphologic studies of bone marrow and blood reveal clear evidence of malignancy. This finding may indicate that the malignancy has not always extended to the peripheral blood in quantity sufficient to be recognized by immunofluorescence or that the malignant cells making up the tumor have derived from cells other than those of the $B$ cell line. Additional studies applying immunofluorescence to the tumor tissue and bone marrow are needed to resolve this question. Such studies should be especially pertinent in patients where perturbations of $B$ cell number and class distribution are not present but in whom depression or imbalance of the immunoglobulins (products of $\mathrm{B}$ cell differentiation) are demonstrable. Such disturbances were seen in six cases reported here. Some such cases will most probably turn out to be $B$ cell malignancies that have not yet extended to the blood. Others, however, will doubtless turn out to be lymphomas of other origins such as $\mathrm{T}$ lymphocytes, monocyte precursors, or various types of stem cells that look morphologically like lymphocytes.

Although Moore, Miglore, Schullenberger, and Alexanian found monoclonal gammopathy in a significant proportion of patients with malignant lymphoma (43), we encountered this abnormality in only one patient, namely in a patient with Waldenström's macroglobulinemia. The peripheral blood lymphocytes of this patient showed a most homogenous population of IgM$\kappa$-bearing cells. These findings differed from those of Preud'homme and Seligmann who reported that their patients with Waldenström's macroglobulinemia had $B$ lymphocytes showing a great variety of fluorescent patterns after staining with anti- $\mu$ sera (44). They interpreted their observations to indicate that in Waldenström's macroglobulinemia the IgM-bearing B lymphocytes represent many different stages of differentiation and maturation into IgM-secreting cells. Our case seems to represent a more homogenous pattern such as that observed in patients with chronic lymphatic leukemia and other patients with solid lymphomas. However, $0.7 \%$ of lymphocytes from the blood of our patient with Waldenström's macroglobulinemia contained IgM- $\kappa$ globulin in the cytoplasm. Whether these or the less mature lymphocytes with only plasma-membrane associated immunoglobulins represent the source of serum immunoglobin in these patients still remains to be determined. The further analysis of this question may, however, require the use of methods designed to evaluate separately the processes of synthesis and secretion of immunoglobulin $(45,46)$. It is of interest that none of the remaining six patients whose monoclonal B lymphocyte proliferation was clearly reflected in the peripheral blood presented a monoclonal immunoglobulin spike in the serum. These cells too should be further evaluated for their separate capacity to synthesize and secrete immunoglobulins.

The B lymphocyte origin of malignant lymphomas has already been postulated. The studies of Stein, Lennert, and Parwaresch using homogenates of tissues that were involved by malignant lymphomas presented evidence for the presence of immunoglobulin of one class in approximately one-half of the tumors (47). The methods used were, however, not adequate to establish the monoclonality of the immunoglobulin or its origin from secretory B cells or B cells with surface immunoglobulin. Indeed, an immune response directed toward tumors might account for such immunoglobulin concentration in tissue homogenates (19). Moore et al. found monoclonal IgM spikes in the serum probably reflecting a monoclonal nature of the lymphoma in approximately $4 \%$ of more than 500 cases of diffuse lymphoma (43). Burkitt's lymphoma has been shown to represent B lymphocytes. The evidence for the presence of plasma membrane-associated monoclonal immunoglobulin was obtained by studying the lymphoma cells directly and in established culture line (48). Aisenberg and Bloch reported three cases of lymphosarcoma cell 
leukemia which had IgM-producing B lymphocytes of an apparent monoclonal pattern in the peripheral blood (17). One cell line from Burkitt's lymphoma, Raji has been found by other criteria to be of $\mathrm{B}$ cell origin even though it lacks surface immunoglobulins (49). Techniques for identifying and evaluating $\mathrm{B}$ lymphocytes are developing rapidly. In addition to the surface immunoglobulin techniques upon which we have relied in this investigation, identification of $\mathrm{B}$ lymphocytes as those having surface receptors for the Fc portion of IgG and receptors for the third component of complement have been and are being used. Excellent agreement between the numbers of lymphocytes identified by these three methods has been obtained in normal healthy persons, but considerable variations have turned up in patients in a variety of diseases $(50,18)$. Since the methodology of the three basic analyses used for B lymphocytes has only recently been perfected, all three were not used in our study. Subsequent analyses using these three techniques and even using along with them scanning electron microscopic techniques to analyze human lymphomatous disease are surely needed.

Advantages of the methods used in this study to analyze malignant lymphomas already seem clear from prior reports of our own material (51). By a relatively simple study of living cells from the lymph node we could establish the existence of a monoclonal proliferation of the lymphoid cells before histologic analysis could detect recurrence of the lymphoma. It seems certain that the methodologies used in this study and application of other markers already available can yield much new, clinically useful, information about malignant lymphomas. It seems certain as well that such fundamental new information about the tumors could have important implications for treatment of the malignancy and management of such patients (52).

\section{ACKNOWLEDGMENTS}

We are indebted to Mrs. Jacqueline Hageman for valuable technical assistance.

This work was aided by grants from The National Foundation-March of Dimes, American Cancer Society, Leukemia Research Fund, The Masonic Hospital Fund, and U. S. Public Health Service (AI-00798, AI-08677, CA-08832, CA-05158, CA-08748-08, CA-08101, and a contract from the National Institutes of Health, SVCP 712261).

\section{REFERENCES}

1. Pernis, B., L. Forni, and L. Amante. 1970. Immunoglobuin spots on the surface of rabbit lymphocytes. J. Exp. Med. 132: 1001.

2. Kincade, P. W., A. R. Lawton, and M. D. Cooper. 1971. Restriction of surface immunoglobulin determinants to lymphocytes of the plasma cell line. $J$. Immunol. 106: 1421.
3. Unanue, E. R., H. M. Grey, E. Rabellino, P. Campbell, and J. Schmidtke. 1971. Immunogloblins on the surface of lymphocytes. II. The bone marrow as the source of detectable surface-bound immunoglobulins. J. Exp. Med. 133: 1188 .

4. Rabellino, E., and H. M. Grey. 1971. Immunoglobulins on the surface of lymphocytes. III. Bursal origin of surface immunoglobulins on chicken lymphocytes. $J$. Immunol. 106 : 1418.

5. Vitetta, E. S., C. Bianco, V. Nussenzweig, and J. W. Uhr. 1972. Cell surface immunoglobulins. IV. Distribution among thymocytes, bone marrow cells, and their derived populations. J. Exp. Med. 136: 81 .

6. Good, R. A. 1957. Morphological basis of the immune response and hypersensitivity. In Host-Parasite Relationship in Living Cells. H. Felton, editor. Charles C Thomas, Publisher, Springfield, Ill. 78.

7. Peterson, R. D. A., M. D. Cooper, and R. A. Good 1965. The pathogenesis of immunologic deficiency diseases. Am. J. Med. 38: 579.

8. Claman, H. N., E. A. Chaperon, and R. F. Triplett 1966. Thymus-marrow cell combinations. Synergism in antibody production. Proc. Soc. Exp. Biol. Med. 122: 1167.

9. Good, R. A. 1973. Immunodeficiency in developmental pespective. Harvey Lect. $67: 1$.

10. Katz, D. H., and B. Benacerraf. 1972. The regulatory influence of activated $\mathrm{T}$ cells on $\mathrm{B}$ cell responses to antigen. Adv. Immunol. $15: 1$.

11. Good, R. A., J. Finstad, and R. A. Gatti. 1970. Bulwarks of the bodily defense. In Infectious agents and host reactions. Stuart Mudd, editor. W. B. Saunders Company, Philadelphia. 76.

12. Good, R. A. 1972. Relations between immunity and malignancy. Proc. Natl. Acad. Sci. U. S. A. 69: 1026.

13. Kersey, J. H., B. D. Spector, and R. A. Good. 1973. Immunodeficiency and cancer. Adv. Cancer Res. In press.

14. Pernis, B., M. Ferrarini, L. Forni, and L. Amante. 1971. Immunoglobulins on lymphocyte membranes. In Progress in Immunology. B. Amos, editor. Academic Press, Inc., New York. 95.

15. Preud'homme, J. L., M. Klein, P. Verroust, and M. Seligmann. 1971. Immunoglobulines monoclonales de membrane dans les leucemies lymphoides chroniques. Rev. Eur. Etud. Clin. Biol. 16: 1025.

16. Wilson, J. D., and G. J. V. Nossal. 1971. Identification of human $\mathrm{T}$ and $\mathrm{B}$ lymphocytes in normal peripheral blood and in chronic lymphocytic leukemia. Lancet. 2: 788.

17. Aisenberg, A. C., and K. J. Bloch. 1972. Immunoglobulins on the surface of neoplastic lymphocytes. N. Engl. J. Med. $287: 272$.

18. Ross, G. D., E. M. Rabellino, M. J. Polley, and H. M. Grey. 1973. Combined studies of complement receptor and surface immunoglobulin-bearing cells and sheep erythrocyte rosette-forming cells in normal and leukemic human lymphocytes. J. Clin. Invest. 52: 377.

19. Gutterman, J. U., R. G. Rossen, W. T. Butler, K. B. McCredie, G. P. Bodey, E. J. Freireich, and E. M. Hersh. 1973. Immunoglobulin on tumor cells and tumor-induced lymphocyte blastogenesis in human acute leukemia. N. Engl. J. Med. 288: 169.

20. Grey, H. M., E. Rabellino, and B. Pirofsky. 1971. Immunoglobulins on the the surface of lymphocytes. IV. Distribution in hypogammaglobulinemia, cellular 
immune deficiency, and chronic lymphocytic leukemia. J. Clin. Invest. $50: 2368$.

21. Siegal, F. P., B. Pernis, and H. G. Kunkel. 1971. Lymphocytes in human immunodeficiency states: a study of membrane-associated immunoglobulins. Eur. J. Immunol. $1: 482$.

22. Cooper, M. D., A. R. Lawton, and D. E. Bockman. 1971. Agammaglobulinaemia with B lymphocytes, specific defect of plasma-cell differentiation. Lancet. 2: 791 .

23. Gaj1-Peczalska, K. J., W. D. Biggar, B. H. Park, and R. A. Good. 1972. B lymphocytes in Di George syndrome. Lancet. $1: 1344$.

24. Gajl-Peczalska, K. J., B. H. Park, W. D. Biggar, and R. A. Good. 1973. B and T lymphocytes in primary immunodeficiency disease in man. J. Clin. Invest. 52: 919.

25. Grifoni, V., G. S. Del Giaco, P. E. Manconi, and S. Tognella. 1972. Surface immunoglobulins on lymphocytes in Hodgkin's disease. Lancet. 1: 848.

26. Cohnen, G., W. Augener, E. König, G. Brittinger, and S. D. Douglas. 1973. B-Lymphocytes in Hodgkin's Disease. N. Engl. J. Med. 288: 161.

27. Falletta, J. M., N. Ramanujam, K. A. Starling, and D. J. Fernbach. 1973. Ig-positive lymphocytes in Hodgkin's disease. N. Engl. J. Med. 288: 581.

28. Park, B. H., and R. A. Good. 1972. A new micromethod of evaluating lymphocyte response to phytohemagglutinin: quantitative analysis of the function of thymus-dependent cells. Proc. Natl. Acad. Sci. U. S. A 69: 371.

29. Lukes, R. J. 1971. Malignant lymphoma: histologic considerations. In Current Concepts in the Management of Lymphoma and Leukemia. J. E. Ultmann, M. L. Griem, W. H. Kirsten, and R. W. Wissler, editors. Springer Verlag, New York. 6.

30. Rappaport, H. 1966. Primary macroglobulinemia of Waldenström. In Tumors of the Hematopoietic System. Armed Forces Institute of Pathology, Washing ton, D. C. 213.

31. Lukes, R. J., J. J. Butler, and E. B. Hicks. 1966 Natural history of Hodgkin's disease as related to its pathologic picture. Cancer. 19: 317

32. Carbone, P. P., H. S. Kaplan, K. Musshoff, D. W. Smithers, and M. Tubiana. 1971. Report of the committee of Hodgkin's disease staging classification. Cancer Res. 31: 1860

33. Russel, D. S., and L. J. Rubinstein. 1959. Microgliomatosis. In Pathology of Tumours of the Nervous System. E. Arnold Publishers Ltd., London. 67.

34. Zimmerman, L. E. 1964. Lymphoid tumors. In Ocular and Adnexal Tumors. New and controversial aspects. M. Boniuk, editor. C. V. Mosby Company, St. Louis, Mo. 429.

35. Front, R. L., M. Yanoff, and L. E. Zimmerman. 1967. Benign lymphoepithelial lesion of the lacrimal gland and its relationship to Sjögren's syndrome. Am. J. Clin. Pathol. 48: 365.

36. Schier, W. W., A. Ruth, G. Ostroff, and M. H. Schrift. 1956. Hodgkin's disease and immunity. Am. J. Med. 20: 94 .
37. Kelly, W. D., R. A. Good, and R. L. Varco. 1958. Anergy and skin homograft survival in Hodgkin's disease. Surg. Gynecol. Obst. 107: 565.

38. Good, R. A., W. D. Kelly, and A. E. Gabrielsen. 1962. Studies of the immunologic deficiency diseases: agammaglobulinemia, Hodgkin's disease and sarcoidosis. In Mechanism of Cell and Tissue Damage Produced by Immune Reactions. 2nd International Symposium on Immunopathology, Brook Lodge. Benno Schwabe \& Co., Basel. 353.

39. Young, R. C., M. P. Corder, H. A. Haynes, and V. T. DeVita. 1972. Delayed hypersensitivity in Hodgkin's disease. A study of 103 untreated patients. Am. J. Med. $52: 63$.

40. Eltringham, J. R., and H. S. Kaplan. 1972. Impaired delayed hypersensitivity responses in 154 patients with untreated Hodgkin's disease. International Symposium on Hodgkin's Disease, Stanford University, March 20 24. In press.

41. Gaj1-Peczalska, K. J., S. D. Lim, R. R. Jacobson, and R. A. Good. 1973. B lymphocytes in lepromatous leprosy. N. Engl. J. Med. 288: 1033.

42. Papmichail, M., E. J. Holborow, H. I. Keith, and H. L. F. Currey. 1972. Subpopulations of human peripheral blood lymphocytes distinguished by combined rosette formation and membrane immunofluorescence. Lancet. 2: 64.

43. Moore, D. F., F. J. Miglore, C. C. Schullenberger, and R. Alexanian. 1970. Monoclonal macroglobulinemia in malignant lymphoma. Ann. Int. Med. 72: 43.

44. Preud'homme, J. L., and M. Seligmann. 1972. Immunoglobulins on the surface of lymphoic cells in Waldenström's macroglobulinemia. J. Clin. Invest. 51: 701.

45. Choi, Y. S., P. M. Knopf, and E. S. Lennox. 1971 Intracellular transport and secretion of immunoglobulin light-chain. Biochemistry. 10:668.

46. Choi, Y. S., W. D. Biggar, and R. A. Good. 1972. Biosynthesis and secretion of immunoglobulins by peripheral blood lymphocytes in severe hypogammaglobulinaemia. Lancet. 1 : 1149.

47. Stein, H., K. Lennert, and M. R. Parwaresch. 1972. Malignant lymphomas of B-cell type. Lancet. 2: 855 .

48. Klein, E., G. Klein, J. S. Nadkarni, J. J. Nadkarni, H. Wigzell, and P. Clifford. 1968. Surface IgM-kappa specificity on a Burkitt lymphoma cell in vivo and in derived culture lines. Cancer Res. 28: 1300.

49. Shevach, E. M., R. Herberman, M. M. Frank, and I Green. 1972. Receptors for complement and immunoglobulin on human leukemic cells and human lymphoblastoid cell lines. J. Clin. Invest. 51: 1933.

50. Bentwich, Z. H., and H. G. Kunkel. 1973. Specific properties of human $\mathrm{B}$ and $\mathrm{T}$ lymphocytes and their alterations in disease. Transplant. Rev. In press.

51. Gaj1-Peczalska, K. J., J. H. Kersey, M. E. Nesbit, and R. A. Good. 1973. B-cell proliferation manifested as acute lymphosarcoma cell leukemia and lymphoma in adolescents. Pediatr. Res. $7: 349$.

52. Good, R. A. 1972. Lymphocyte surface markers. Nezo Engl. J. Med. 287: 305. (Editorial) 